\title{
Bycatch of protected species and other species of concern in US east coast commercial fisheries
}

\author{
Erika A. Zollett* \\ MRAG Americas, Inc., 65 Eastern Avenue, Unit B2C, Essex, Massachusetts 01929, USA
}

\begin{abstract}
Bycatch, the incidental capture of any marine animal in fishing gear, occurs globally in nearly every type of fishing gear. This paper consolidates the existing published and unpublished information about bycatch of protected species and other species of concern in commercial fishing gear on the east coast of the United States. A total of 49 commercial fisheries were reviewed, 39 of which had documented bycatch. The study identifies documented and potential bycatch of marine mammal, sea turtle, sea bird, fish, and invertebrate species in addition to existing bycatch mitigation and management in these fisheries. This information can be used as a resource for scientists, managers, and conservation practitioners in understanding the extent of bycatch and bycatch mitigation on the US east coast.
\end{abstract}

KEY WORDS: Bycatch · Protected species · Species of concern · US east coast · Commercial fisheries

\section{INTRODUCTION}

Bycatch is the incidental capture of any marine animal in fishing gear. It has been defined as the portion of catch that is not targeted and that has no economic value, either because no markets exist for a species or because its retention is prohibited by law (Hall 1996). Bycatch has negative consequences including gear damage, lost fishing time, lost income, and safety concerns for fishermen, as well as injury and death for marine animals (Hall 1996). It can also have adverse effects on an ecosystem through the removal of top predators, large quantities of individuals, and important prey resources (Hall et al. 2000). Marine animals that are incidentally captured in fishing gear include marine mammal, sea turtle, sea bird, fish, and invertebrate species. Bycatch is a leading conservation concern for long-lived species with low reproductive rates (Hall et al. 2000), particularly endangered or threatened species with already small population sizes. It threatens marine animals globally and in nearly every type of fishing gear (Northridge 1991, Read \& Rosenberg 2002).
To date, most research on bycatch has focused on a single species, taxonomic group, or fishery, making it difficult to understand the extent and cumulative impacts of the problem. Compounding the issue, bycatch management across taxa is inconsistent, and coverage by fishery observers is low. In a recent paper, Moore et al. (2009) review the US policies on bycatch that pertain to marine mammals, sea turtles, and sea birds.They detail the gaps and policy limitations that restrict the efficacy of multi-species bycatch reduction efforts in the USA and call for consistent criteria across taxa for setting bycatch limits by suggesting that the existing approach for marine mammals be applied to sea turtles and sea birds.

The synthesis by Moore et al. (2009) provides a rationale for taking a multi-species approach to bycatch research and management and a broad overview of marine mammal, sea turtle, and sea bird bycatch in US fisheries. In the present study, I aim to provide a multispecies investigation on a fishery-specific basis of bycatch in the Atlantic Ocean by US commercial fishing operations. I consolidate the available information on bycatch of protected species and other species of 
concern in fisheries off the east coast of the United States into a single resource for scientists, managers, and conservation practitioners. This study is the first of its kind to provide such a fine resolution analysis of multi-species bycatch in these fisheries. In addition to marine mammal, sea turtle, and sea bird species, I also summarize documented bycatch of fish and invertebrate species. Criteria for the inclusion of a species in the study are discussed in 'Materials and methods'. The criteria are based on protections afforded to certain species based on US fisheries management or on the identification of species as being at risk due to bycatch interactions. In addition to documented bycatch events, I also infer, from knowledge of existing bycatch in similar fisheries, where bycatch may potentially occur (see Tables).

\section{MATERIALS AND METHODS}

I obtained a list of US east coast commercial fisheries from the 2009 List of Fisheries developed by the National Oceanic and Atmospheric Administration (NOAA). I included all US commercial fisheries that occurred in the Northwest Atlantic Ocean between Maine and Florida in this analysis, with the exception of dive fisheries and aquaculture facilities. I excluded dive fisheries because of the selective nature of these fisheries, which results in little to no bycatch. I included fisheries that occurred in this area in addition to another region, such as the Caribbean or the Gulf of Mexico, and noted the distribution of each fishery. However, fisheries that occurred solely in the Caribbean or Gulf of Mexico were not included.

I investigated all documented interactions in published and unpublished literature and data that occurred between protected species or species of concern and commercial fishing operations in the study area. I present data in tables organized by type of fishing gear, type of target and non-target catch, and the status of bycatch mitigation and management in each fishery. I used the most up-to-date literature and data, due to recent changes in Northwest Atlantic fisheries in response to management measures. For each fishery, I also included the category of each commercial fishery as classified by NOAA depending on the status of its interactions with marine mammals (NOAA 2008a). Category I or II fisheries have the highest levels of bycatch and must carry a fishery observer if requested by the NOAA (NOAA 2008a).

In fisheries where observations are limited, I extrapolated what is currently known about bycatch in similar fisheries to the fishery in question. I included a category for this potential bycatch in the tables to represent where it is believed that interactions may occur but have not been documented. For instance, since it is known that large whales can become entangled in vertical lines of lobster pot gear, I extrapolated that they are likely to face the same threat from other pot fisheries found within the range of their distribution. Therefore, I included potential bycatch (1) where spatial overlap is known to exist between a species or taxonomic group and a fishery, and (2) where bycatch is known to occur in similar fishing gear. I provided species' names where applicable and available; otherwise, I listed the taxonomic group for the potential bycatch category. The likelihood and extent of bycatch are not only dependent on the spatial overlap between a species and fishery but also on the density of a species. The latter is not considered in this paper.

This study focuses on bycatch of protected species and other species of concern and does not attempt to be comprehensive in listing all species caught as bycatch. The criteria for inclusion of species in the present study varied between taxa, due to differences in the data available and the management policies for the respective groups, and are discussed in the sections below.

Marine mammals. Seven marine mammal species on the US east coast are protected as a result of listings in the Endangered Species Act (ESA); these include blue Balaenoptera musculus, humpback Megaptera novaeangliae, fin B. physalus, sei B. borealis, sperm Physeter macrocephalus, and North Atlantic right whales Eubalaena glacialis in addition to the West Indian manatee Trichechus manatus latirostris. Of these species, fin, humpback, and North Atlantic right whales are those most likely to interact with commercial fishing gear. In addition to the ESA, the Marine Mammal Protection Act (MMPA) provides protections to all marine mammals in US waters. Thus, I included documented interactions between all marine mammals and commercial fisheries on the US east coast.

According to the Stock Assessment Reports provided by NOAA (1995, 1998a, 2002a, 2005, 2007a) and the USFWS (2000), east coast commercial fisheries interacted with 22 species (24 stocks) of marine mammals (Table 1). There were no observed or reported interactions between commercial fishing activities on the US east coast and protected blue and sei whales; however, it is possible that bycatch may be occurring but has not been documented by fishery observers (S. Kraus pers. comm., March 2009).

Sea turtles. All 6 sea turtle species found in US waters are listed in the ESA. Five of these can be found in US east coast waters and were thus included in the present study: green Chelonia mydas, hawksbill Eretmochelys imbricata, leatherback Dermochelys coriacea, loggerhead Caretta caretta, and Kemp's ridley Lepidochelys kempii turtles. 
Table 1. Marine mammal species that have been documented as bycatch by fishery observers in east coast commercial fisheries, according to individual NOAA Stock Assessment Reports (NOAA 1995, 1998a, 2002a, 2005, 2007a and USFWS 2000). MMPA: Marine Mammal Protection Act; ESA: Endangered Species Act; PBR: potential biological removal

\begin{tabular}{|c|c|c|}
\hline $\begin{array}{l}\text { Species with } \\
\text { documented bycatch }\end{array}$ & Scientific name & Status \\
\hline \multicolumn{3}{|l|}{ Small cetaceans } \\
\hline $\begin{array}{l}\text { Bottlenose dolphin } \\
\text { (coastal and } \\
\text { offshore stocks) }\end{array}$ & Tursiops truncatus & $\begin{array}{l}\text { Listed as depleted under the MMPA (coastal stock); not listed under } \\
\text { the ESA, but status is unknown due to insufficient information on } \\
\text { population trends and interactions with commercial fisheries } \\
\text { (offshore stock) }\end{array}$ \\
\hline Common dolphin & Delphinus delphis & $\begin{array}{l}\text { Serious injury and mortality do not exceed PBR, but takes do exceed } 10 \% \text { of } \\
\text { PBR, i.e. they are not insignificant and not approaching zero mortality }\end{array}$ \\
\hline $\begin{array}{l}\text { Atlantic white- } \\
\text { sided dolphin }\end{array}$ & Lagenorhyncus acutus & $\begin{array}{l}\text { Serious injury and mortality do not exceed PBR, but takes do exceed } 10 \% \text { of } \\
\text { PBR, i.e. they are not insignificant and not approaching zero mortality }\end{array}$ \\
\hline Risso's dolphin & Grampus griseus & $\begin{array}{l}\text { Serious injury and mortality do not exceed PBR, but takes do exceed } 10 \% \text { of } \\
\text { PBR, i.e. they are not insignificant and not approaching zero mortality }\end{array}$ \\
\hline $\begin{array}{l}\text { Atlantic spotted } \\
\text { dolphin }\end{array}$ & Stenella frontalis & Takes are approaching zero or $<10 \%$ of PBR \\
\hline $\begin{array}{l}\text { Atlantic pantropical } \\
\text { spotted dolphin }\end{array}$ & Stenella attenuata & Takes are approaching zero or $<10 \%$ of PBR \\
\hline Striped dolphin & Stenella coeruleoalba & Takes are approaching zero or $<10 \%$ of PBR \\
\hline Harbor porpoise & Phocoena phocoena & Listed under the ESA; bycatch exceeds PBR \\
\hline \multicolumn{3}{|l|}{ Large whales } \\
\hline Humpback whale & Megaptera novaeangliae & Listed under the ESA; bycatch exceeds PBR \\
\hline Minke whale & Balaenoptera acutorostrata & $\begin{array}{l}\text { Serious injury and mortality do not exceed PBR, but takes do exceed } 10 \% \text { of } \\
\text { PBR, i.e. they are not insignificant and not approaching zero mortality }\end{array}$ \\
\hline Fin whale & Balaenoptera physalus & Listed under the ESA \\
\hline $\begin{array}{l}\text { North Atlantic } \\
\text { right whale }\end{array}$ & Eubalaena glacialis & Listed under the ESA; bycatch exceeds PBR \\
\hline Sperm whale & Physeter macrocephalus & Listed under the ESA but takes are below $10 \%$ of PBR \\
\hline \multicolumn{3}{|l|}{ Small whales } \\
\hline $\begin{array}{l}\text { Long and short- } \\
\text { finned pilot whales }\end{array}$ & $\begin{array}{l}\text { Globicephala melas, } \\
\text { Globicephala } \\
\text { macrorhynchus }\end{array}$ & $\begin{array}{l}\text { Serious injury and mortality do not exceed PBR, but takes do exceed } 10 \% \text { of } \\
\text { PBR, i.e. they are not insignificant and not approaching zero mortality } \\
\text { While takes of short- and long-finned pilot whales combined do not } \\
\text { exceed PBR, there is concern about the possibility of serious injury or } \\
\text { mortality of one stock or the other exceeding PBR }\end{array}$ \\
\hline Cuvier's beaked whale & Ziphius cavirostris & Takes are approaching zero or $<10 \%$ of PBR \\
\hline $\begin{array}{l}\text { Mesoplodon beaked } \\
\text { whale }\end{array}$ & Mesoplodon spp. & Takes are approaching zero or $<10 \%$ of PBR \\
\hline Pygmy sperm whale & Kogia breviceps & Takes are approaching zero or $<10 \%$ of PBR \\
\hline \multicolumn{3}{|l|}{ Pinnipeds } \\
\hline Harbor seal & Phoca vitulina & $\begin{array}{l}\text { Serious injury and mortality do not exceed PBR, but takes do exceed } 10 \% \text { of } \\
\text { PBR, i.e. they are not insignificant and not approaching zero mortality }\end{array}$ \\
\hline Harp seal & Pagophilus groenlandicus & $\begin{array}{l}\text { Takes are approaching zero or }<10 \% \text { of PBR. While bycatch is } \\
\text { approaching zero in US fisheries, there is a directed fishery in Canada } \\
\text { that takes an estimated } 447442 \text { harp seals annually (NOAA 2007a) }\end{array}$ \\
\hline Gray seal & Halichoerus grypus & Takes are approaching zero or $<10 \%$ of PBR \\
\hline Hooded seal & Cystophora cristata & Takes are approaching zero or $<10 \%$ of PBR \\
\hline \multicolumn{3}{|l|}{ Sirenians } \\
\hline $\begin{array}{l}\text { West Indian } \\
\text { manatee }\end{array}$ & $\begin{array}{l}\text { Trichechus manatus } \\
\text { latirostris }\end{array}$ & $\begin{array}{l}\text { Listed under the ESA; bycatch exceeds PBR. A high level of mortality } \\
\text { has been documented relative to the estimated population level, and } \\
\text { continuing threats to this stock exist }\end{array}$ \\
\hline
\end{tabular}

Sea birds. Only 2 sea bird species on the US east coast, the Bermuda petrel Pterodroma cahow and the roseate tern Sterna dougallii, are listed in the ESA; however, there has been no documented bycatch of either of these species (M. Warden pers. comm., December 19, 2008). Furthermore, interactions with fisheries have not been identified to be a conservation threat to either of these protected bird species (SAFMC 2008). 
Since it is known that bycatch of other sea bird species exists and may pose a threat to sea bird populations or species, I extended the criteria for which sea birds would be investigated to include sea bird species that have been identified by regional partnerships as threatened by interactions with fisheries. In the mid-Atlantic and New England regions, the Mid-Atlantic/New England/Maritime Regional Working Group (MANEM), a regional collaboration between organizations and individuals to facilitate waterbird conservation, identified negative fisheries interactions as a serious threat to populations of red-throated loon Gavia stellata, common loon G. immer, red-necked grebe Podiceps grisegena, northern fulmar Fulmarus glacialis, greater shearwater Puffinus gravis, sooty shearwater Puffinus griseus, manx shearwater Puffinus puffinus, northern gannet Morus bassanus, herring gull Larus argentatus, sabine's gull Xema sabini, black-legged kittiwake Rissa tridactyla, pomarine jaeger Stercorarius pomarinus, common murre Uria aalge, thick-billed murre $U$. lomvia, razorbill Alca torda, black guillemot Cepphus grylle, and Atlantic puffin Fratercula arctica (Le Boeuf 2007). Of these, the red-throated loon, red-necked grebe, greater shearwater, northern gannet, thickbilled murre, razorbill, black guillemot and the Atlantic puffin have also been identified as species at risk due to fisheries bycatch (Le Boeuf 2007). In the Southeast region, the Southeast US Waterbird Conservation Plan, an initiative focused on conserving waterbird populations and habitat in thirteen states - Texas, Oklahoma, Arkansas, Kentucky, Tennessee, Louisiana, Mississippi, Alabama, Florida, Georgia, South Carolina, North Carolina, and Virginia-identified populations of redthroated loon, common loon, northern gannet, horned grebe Podiceps auritus, black-capped petrel Pterodroma hasitata, Bermuda petrel, and Audubon's shearwater Puffinus lherminieri as negatively impacted by interactions with fisheries (Le Boeuf 2007).

Fish. Protected fish species that are listed on the ESA and occur in the study area include the smalltooth sawfish Pristis pectinata, Atlantic salmon Salmo salar, and shortnose sturgeon Acipenser brevirostrum. Although shortnose sturgeon occur only in rivers and estuaries and are more likely to be threatened by construction of dams and pollution than by commercial fishery operations (NMFS 2002), bycatch of this species still occurs and can threaten this endangered species. Although bycatch is not listed as a factor for the decline of the Atlantic salmon (NOAA 2007b, it is unknown whether bycatch threatens the continued existence of this species.

For fish, the criteria for inclusion in the present study were extended to include 'species of concern.' Species of concern are those that have been identified as being potentially at risk by the NOAA Office of Protected Re- sources (OPR); however, information is insufficient, and status and threats are too uncertain to merit a listing under the ESA (NOAA 2009). Thus, I investigated the species of concern which have either their entire, or a part of, their habitat distribution along the US east coast and which have been identified by the NOAA OPR as threatened due to bycatch. The species that fit these criteria are river herring (alewife Alosa pseudoharengus and blueback herring Alosa aestivalis), Atlantic sturgeon Acipenser oxyrinchus oxyrinchus, Atlantic wolffish Anarhichas lupus, barndoor skate Dipturus laevis, cusk Brosme brosme, dusky shark Carcharhinus obscurus, night shark Carcharinus signatus, sand tiger shark Carcharias taurus, speckled hind Epinephelus drummondhayi, thorny skate Amblyraja radiate, and warsaw grouper E. nigritus (NOAA 2007b, 2008b).

Bycatch is only one of the threats to these species. It should be noted that some of these species are targeted by fishing efforts (NOAA 2007b, 2008b), while others are not targeted but are landed if captured. For instance, skates are caught incidentally while targeting other species, including monkfish and scallops, and they are landed only if the price is high enough to warrant the effort to prepare the wings (NOAA 2002d). There is no directed fishery for barndoor skates; thus, boats landing skate wings are likely catching them incidentally (NOAA 2002d).

Invertebrates. Elkhorn Acropora palmata and staghorn Acropora cervicornis coral are 2 invertebrate species listed in the ESA and found in waters off the US Southeast. Bycatch is not listed as a conservation concern for these species (Acropora Biological Review Team 2005). No additional invertebrates species found on the US east coast are 'species of concern' as identified by NOAA (NOAA 2009).

\section{RESULTS AND DISCUSSION}

Forty-nine commercial fisheries were identified on the US east coast, 39 of which have documented bycatch. Gillnet and longline fisheries resulted in the highest number of species that were documented as bycatch (Table 2). The specific fisheries with documented bycatch of the high number of species were: the Atlantic, Caribbean, Gulf of Mexico large pelagics longline; Northeast sink gillnet; and Mid-Atlantic gillnet fisheries. Additional results are presented by fishing gear type.

\section{Gillnets}

Twelve commercial gillnet fisheries were researched, 10 of which experienced bycatch (see Table S1 in Supplement 1, available at: www.int-res.com/articles/ 
Table 2. Documented bycatch interactions for each taxonomic group by fishing gear type. Data correspond to the number of species investigated in the present study that were documented as bycatch in the corresponding fishing gear type. No ESA-listed sea bird species were documented as bycatch; the species included in this table are those that have been identified as being threatened in part by interactions with fisheries. MMPA: species listed under the Marine Mammal Protection Act; ESA: species listed under the Endangered Species Act

\begin{tabular}{|c|c|c|c|c|c|c|c|}
\hline \multirow{2}{*}{$\begin{array}{l}\text { Gear } \\
\text { type }\end{array}$} & \multicolumn{2}{|c|}{ Marine mammals } & \multirow{2}{*}{$\begin{array}{c}\text { Sea turtles } \\
\text { ESA }\end{array}$} & \multirow{2}{*}{$\begin{array}{l}\text { Sea birds } \\
\text { Regional }\end{array}$} & \multicolumn{2}{|c|}{ Fish $\longrightarrow$} & \multirow{2}{*}{ Total } \\
\hline & ESA & MMPA only & & & ESA & Species of concern & \\
\hline Gillnets & 3 & 12 & 4 & 14 & 2 & 6 & 41 \\
\hline Longlines & 1 & 15 & 6 & 3 & 1 & 8 & 34 \\
\hline Trawls & 1 & 11 & 4 & 4 & 2 & 4 & 26 \\
\hline Traps/pots & 4 & 3 & 3 & 0 & 1 & 2 & 13 \\
\hline Purse seines & 2 & 5 & 0 & 0 & 0 & 1 & 8 \\
\hline Dredges & 0 & 0 & 4 & 3 & 0 & 2 & 9 \\
\hline $\begin{array}{l}\text { Pound nets, } \\
\text { stop nets, } \\
\text { seines, weirs }\end{array}$ & 0 & 6 & 4 & 1 & 1 & 1 & 13 \\
\hline
\end{tabular}

suppl/n009p049_app.pdf). Gillnets in all 3 regions resulted in considerable bycatch, and management measures are in place in over half of these fisheries in response to bycatch of sea turtles and marine mammals (Table 3). In the mid-Atlantic gillnet fishery, sep- arate bycatch management regulations are in place for large whales, bottlenose dolphins, harbor porpoise, and sea turtles.

In the Northeast, a combination of time and area closures and acoustic devices, or pingers, has proven suc-

Table 3. Existing management regulations or recommended voluntary measures have been implemented in several of the reviewed fisheries to address protected species bycatch. 'Sea turtle regulations' include state and federal regulations designed specifically to reduce bycatch of sea turtles. NE: Northeast USA; SE = Southeast USA; M-A = US Mid-Atlantic; P: proposed measures; G: gear requirements and/or modifications; B: bait requirements; T: regulations that apply to certain times and/or areas; C: seasonal/area closures; I: included in plan, but no regulatory measures exist; V: voluntary measures; R: required release protocols and/or equipment. Numbers in parentheses refer to sources as follows: (1) NOAA (1999); (2) Borggaard et al. (2008); (3) NOAA (2006); (4) NOAA (1998b); (5) NOAA (2008e); (6) ATGTRT (2008); (7) NOAA (2002c); (8) NOAA (2002b); (9) NOAA (2004); (10) NMFS \& USFWS (2008) (11) NOAA (2008d); (12) NOAA (2008c). These regulations include state and federal regulations designed specifically to reduce bycatch of sea turtles

\begin{tabular}{|c|c|c|c|c|c|c|}
\hline Fishery & $\begin{array}{l}\text { Large } \\
\text { whale }\end{array}$ & $\begin{array}{l}\text { Bottlenose } \\
\text { dolphin }\end{array}$ & $\begin{array}{l}\text { Harbor } \\
\text { porpoise }\end{array}$ & $\begin{array}{l}\text { Atlantic pelagic } \\
\text { longline }\end{array}$ & $\begin{array}{l}\text { Atlantic } \\
\text { trawl gear }\end{array}$ & $\begin{array}{l}\text { Sea turtle } \\
\text { regulations }\end{array}$ \\
\hline M-A gillnet & $\mathrm{G}, \mathrm{T}(1,2)$ & G, T (3) & $\mathrm{C}, \mathrm{G}, \mathrm{T}(4)$ & & & C, G, T (7) \\
\hline NE sink gillnet & C, G, T $(1,2)$ & & C, G, T (4) & & & \\
\hline NE anchored float gillnet & C, G, T (2) & & & & & \\
\hline NE drift gillnet & $\mathrm{C}, \mathrm{G}, \mathrm{T}(2)$ & & & & & \\
\hline SE shark gillnet & $\mathrm{C}, \mathrm{G}, \mathrm{T}(1,2)$ & G, T (3) & & & & \\
\hline SE gillnet & C, G (2) & $\mathrm{G}, \mathrm{T}(3)$ & & & & \\
\hline North Carolina inshore gillnet & & I (3) & & & & C, G, T (8) \\
\hline Large pelagics longline & & & & $\mathrm{P}(5)$ & & $\mathrm{B}, \mathrm{G}, \mathrm{R}, \mathrm{T}(9)$ \\
\hline M-A mid-water trawl & & & & & $\mathrm{V}(6)$ & \\
\hline M-A bottom trawl & & & & & $\mathrm{V}(6)$ & $\mathrm{G}, \mathrm{T}(10)$ \\
\hline NE mid-water trawl & & & & & $\mathrm{V}(6)$ & \\
\hline NE bottom trawl & & & & & $\mathrm{V}(6)$ & \\
\hline SE shrimp trawl & & & & & & C, G (10) \\
\hline Shellfish bottom trawl & & & & & & $\mathrm{C}, \mathrm{G}, \mathrm{T}(10)$ \\
\hline $\begin{array}{l}\text { Georgia cannonball } \\
\text { jellyfish trawl }\end{array}$ & & & & & & G (10) \\
\hline NE/M-A American lobster pot & C, G, T $(1,2)$ & & & & & \\
\hline Blue crab trap/pot & G, T (2) & V (3) & & & & \\
\hline Mixed species trap/pot & $\mathrm{C}, \mathrm{G}, \mathrm{T}(2)$ & & & & & \\
\hline NE/M-A sea scallop dredge & & & & & & G, T (11) \\
\hline Virginia pound net & & I (3) & & & & G, T (12) \\
\hline North Carolina roe mullet stop net & & I (3) & & & & \\
\hline North Carolina long haul seine & & I (3) & & & & \\
\hline M-A haul/beach seine & & I (3) & & & & \\
\hline
\end{tabular}


cessful at reducing incidental takes of harbor porpoise in gillnets from 2900 ind. in 1990 to 323 ind. in 1999 (Read et al. 2006). These measures may also have reduced bycatch of Atlantic white-sided dolphins in Northeast sink gillnets (Read et al. 2006). Estimated bycatch of this species was highest in the period 1992 to 1994 but decreased in subsequent years, most likely as a result of the implementation of bycatch mitigation measures to reduce harbor porpoise bycatch in gillnets (Read et al. 2006). Despite this success, a lack of compliance with pinger requirements may be responsible for recent observed increases in harbor porpoise bycatch; however, habituation or poor pinger maintenance may also be to blame (Read 2000). Another possible explanation recently identified by the NOAA for the increase in takes is that bycatch is occurring outside of areas currently managed by the Harbor Porpoise Take Reduction Plan.

Although pingers have been successful for harbor porpoise in the Gulf of Maine, their effectiveness appears to be fishery and species specific (see Barlow \& Cameron 2003, Cox et al. 2003). Behavioral differences between species suggest different solutions may be needed to address bycatch.

Other mitigation measures, such as the use of tiedowns, have been implemented for marine mammal bycatch in gillnet gear. Tie-downs, a gear requirement for gillnet fishing gear, have been mandated to reduce harbor porpoise bycatch; however, they may increase mortality of Atlantic sturgeon in gillnet gear (ASMFC 2007).

A number of mitigation measures have also been developed to reduce bycatch of seabirds in gillnets, including visible net panels and barium sulphate nets (see Melvin et al. 1999, Trippel et al. 2003). Despite this research, no mitigation measures have as yet been implemented on the east coast of the United States to reduce bycatch of sea birds.

In the Northwest Atlantic, a number of US states, including Georgia, South Carolina, and Florida, have prohibited most gillnets and entangling nets in state waters (NMFS 2002, 2009). Thus, there is very little gillnetting in waters off the US southeast coast, which has led to decreases in sea turtle bycatch (NMFS 2002). The gillnet ban in Florida also has an impact on the recovery of smalltooth sawfish which are extremely vulnerable to capture in gillnets. If the ruling was reversed or weakened in Florida's state waters, this could have detrimental impacts on this species (NMFS 2009). As the recovery of the smalltooth sawfish extends beyond Florida's waters, gillnets will become a serious threat to the success of recovery efforts (NMFS 2009). Gillnetting remains active in other areas, especially in the mid-Atlantic and in federal waters (NMFS \& USFWS 2008). While regulations are in place in the
Mid-Atlantic for gear with mesh greater than 7 inches $(17.8 \mathrm{~cm})$ stretched, it is known that smaller mesh also capture and kill marine life, including sea turtles (NOAA 2002c).

\section{Longlines and hook and lines}

Seven longline and hook and line fisheries were reviewed, 5 of which experienced bycatch (see Table S2 in Supplement 1, available at: www.int-res. com/articles/suppl/n009p049_app.pdf). The Atlantic Ocean, Caribbean, and Gulf of Mexico large pelagics longline fishery catches or has the potential to catch the largest number of marine species (Table S2). This fishery is the only hook and line fishery on the East Coast with existing regulatory or voluntary measures to address bycatch of protected species or species of concern (Table 3). Documented bycatch in this fishery includes marine mammals, sea turtles, sea birds, sharks, and billfish, and the potential exists for bycatch of other sea bird and ray species (Table S2). The potential also exists for ray species to be caught in the large pelagics longline fishery (Mandelman et al. 2008).

Pelagic longlines, which can be up to $100 \mathrm{~km}$ in length and can carry up to 3500 barbed hooks, are believed to be generally more selective than trawl and gillnet gear and do not directly damage habitat (Alverson et al. 1996, Brothers et al. 1999, Gilman et al. 2006). Bycatch has been known to occur with multiple taxonomic groups most likely as a result of depredation, or marine animals feeding on baited hooks, while a smaller number of incidences are believed to result from an animal becoming entangled in gear that was not perceived (Gilman et al. 2006). These behaviors, which occur on longline and hook and line gear, lead to lost fish and gear for fishermen, and often injury and death to marine animals (Zollett \& Read 2006). These interactions can also cause fishermen to take retaliatory measures to protect their gear and catch (Donoghue et al. 2003, Zollett \& Read 2006). Zollett \& Read (2006) devised a gear modification that would deter bottlenose dolphins from engaging in depredation of fish from a hook and line troll fishery in Florida; however, no such gear modification has been devised for longline gear.

Despite the absence of such gear modification, a number of bycatch mitigation measures have been tested and implemented in longline fisheries throughout the world, usually by taxonomic group. For sea turtles, mitigation measures in longline fisheries have focused on regulatory controls on effort, such as limits to seasonal bycatch levels, fishing areas, and fishing seasons; voluntary communication systems in fishing fleets which report occurrence of bycatch; safe han- 
dling and release practices for increasing the likelihood of survival; and modifications to fishing gear and methods (Gilman et al. 2006, NMFS 2008). Modifications or restrictions to fishing gear have included limits on branch line or mainline lengths, requirement of corrodible hooks, reduced fishing effort at shallow depths, or changes in effort associated with frontal systems (NMFS 2008).

Two mitigation measures implemented in the Northwest Atlantic large pelagics fishery include the use of circle hooks instead of ' $\mathrm{J}$ ' style fishing hooks and the use of fish rather than squid bait; these modifications have been shown to effectively reduce sea turtle bycatch. Circle hooks in this swordfish fishery have not only decreased the capture rates of leatherback and loggerhead sea turtles, but they have also decreased the incidence of hooks being swallowed by loggerheads (Watson et al. 2003, 2004, 2005, Shah et al. 2004). As a result, it is widely believed that circle hooks are more likely to hook an animal in the mouth, whereas ' $\mathrm{J}$ ' hooks are often more deeply swallowed (NMFS 2008). Loggerhead sea turtles, which are often caught as a result of depredation, are captured when they attempt to eat bait, and leatherback sea turtles are more likely to become entangled in the gear (NMFS 2008). Some evidence suggests that turtles captured in hook and line fisheries are released alive, but the ingestion of hooks and entanglement in monofilament and steel line likely cause some turtles to strand or die (NMFS \& USFWS 2008). It is important to note that generalizations regarding hooks and baits can be misleading as their effectiveness varies by fishery, target species, and hook size and degree of offset (NMFS 2008).

Circle hooks impact bycatch of other taxa besides sea turtles. Pelagic longline fishing is the primary source of mortality for billfish species, including sailfish, swordfish, and blue and white marlin (Cramer 2004). Several studies have found that a higher mortality of these species corresponds to deeper hooking which occurs when ' $\mathrm{J}$ ' hooks rather than circle hooks are used (see NMFS 2008). The deep-hooking may be related to the level of offset of a hook, with a higher degree of offset corresponding to deeper hooking (NMFS 2008).

Reductions in sea bird bycatch have also been attributed to circle hooks. Observer data from the Northwest Atlantic indicate that seabird bycatch may be 6 times lower on circle hooks than on 'J' hooks (NMFS 2008). Further studies are needed to confirm this finding (NMFS 2008). Other mitigation measures for sea bird bycatch in hook and line fisheries have been tested and implemented in other parts of the world. Those that have been successful or that have shown promise include paired streamers, side-setting practices, bait setting capsules, weighted branchlines, bait pods, and smart hooks (NMFS 2008). In the USA, research and management of sea bird bycatch has focused largely in the Pacific Ocean fisheries where interactions with albatross occur (NMFS 2008). To date, no management measures for sea bird bycatch have been implemented in fisheries of the US east coast.

For marine mammal interactions with longline gear, mitigation strategies that have been employed or that have show promise include: using shorter sets of gear; hauling back gear at faster rates; prohibiting haulbacks in areas with marine mammals; using surface buoys with no longlines as a decoy; avoiding hotspots of marine mammals; moving if depredation occurs; and reducing noise associated with haulbacks (Donoghue et al. 2003, NMFS 2008). In the Atlantic pelagic longline fishery, mitigation measures have been proposed specifically for pilot whales and Risso's dolphins by the Pelagic Longline Take Reduction Team, which was convened in 2005 to devise a strategy to reduce bycatch in the mid-Atlantic region of the Atlantic pelagic longline fishery (NOAA 2008e). Bycatch for pilot whales has increased since circle hooks were mandated in 2004 (Fairfield-Walsh \& Garrison 2007).

\section{Trawls}

Seven commercial trawl fisheries were investigated, all of which have documented bycatch (see Table S3 in Supplement 1, available at: www.int-res.com/articles/ suppl/n009p049_app.pdf). All of these fisheries have either regulatory or recommended voluntary measures to reduce bycatch of protected species (Table 3). Turtle excluder devices (TEDs), the best known method for bycatch reduction in trawl fisheries, were implemented to address sea turtle bycatch and are now mandated in areas throughout the US east coast, including the state waters off Georgia (NMFS \& USFWS 2008). TEDs may also be beneficial for other taxa, as other large organisms such as sharks may be able to escape through these devices. Similar excluder devices have been tested in other parts of the world to reduce bycatch of marine mammals in trawl gears, but the results have been variable (Gibson \& Isakssen 1998, Northridge 2003a,b, Northridge et al. 2003, 2004). Excluder devices for marine mammals have not been tested or implemented in the United States. Additional gear modifications have been developed on the US east coast to reduce bycatch in trawl gear; however, the focus has been on species such as cod and haddock that do not fit the criteria for inclusion in the present study.

In addition to gear modifications, areas along the US east coast are closed to trawl fisheries. Although often 
implemented for a single species or taxa, such as reduction of cod catch in New England, time and area management or fishery closures protect multiple species and taxa that frequent the areas closed to fishing efforts. However, the impacts of displaced fishing effort need to be considered for species that use areas where trawl gear is relocated.

Finally, the Atlantic Trawl Gear Take Reduction team has recently identified several voluntary measures that fishermen in the Northeast and Mid-Atlantic can take to reduce marine mammal bycatch. These measures include reducing the number of turns made by the fishing vessel, decreasing tow times at night, and increasing communication between fishermen as to sightings or incidental takes of marine mammals (ATGTRT 2008).

\section{Traps and pots}

Seven commercial trap and pot fisheries on the US east coast were included in the present review, 5 of which have documented bycatch (see Table S4 in Supplement 1, available at: www.int-res.com/articles/ suppl/n009p049_app.pdf). Management measures that are in place to reduce bycatch in 3 of these fisheries have been developed for large whales (Table 3). Large whales, including the endangered North Atlantic right whales, become entangled in pot gear when parts of their bodies, particularly their mouths or flippers, catch the float or buoy lines. Right whales are particularly vulnerable to mouth entanglements since they are skim feeders, meaning they swim with their mouths open and filter small prey species from the water. A number of gear modifications including sinking groundlines and breakaway or weak links have been designed to reduce entanglement of large whales in pot gear. Some of these modifications have been integrated into existing management on the US east coast. DeAlteris (1999) developed and tested an acoustic release system for offshore lobster buoy lines to reduce right whale entanglements with vertical lines in the Gulf of Maine and southern New England lobster pot fishery; however, this gear has not been adopted by the east coast fishery. The NMFS and the Atlantic Large Whale Take Reduction Team are considering options to reduce the risk to large whales from vertical lines.

Sea turtles also become entangled in vertical lines of trap and pot gear and may subsequently drown (NMFS \& USFWS 2008). Stranded turtles have been recovered surrounded by trap gear. It has been contended that leatherback sea turtles are the most susceptible sea turtle species to entanglement in fishing gear, including trap and pot gear (SAFMC 2004), while other reports argue that loggerhead sea turtles are particularly susceptible to entanglement in pot gear due to their attraction to and attempts to feed on bait in the traps (NMFS \& USFWS 2008).

Depredation from pot gear is also a problem with regard to cetacean and pinniped species. Cetaceans and pinnipeds have been known to enter pot gear in an attempt to eat the bait or catch, and occasionally become trapped and drown. Noke \& Odell (2002) devised a technique to modify the design of crab pots, which prevented dolphins from opening pot doors, entering the gear, and taking bait fish. These gear modifications are included in the voluntary efforts of the Atlantic blue crab pot fishery to reduce bycatch (Table 3). Noke \& Odell (2002) noted that dolphins were not only becoming trapped in pot gear while engaging in depredation, but that they also became entangled in float and buoy lines. Similar to large whales, smaller marine mammals are also bycaught in pot gear by swimming into the gear and becoming entangled.

\section{Purse seines}

Four commercial purse seine fisheries on the US east coast were included in the present review, and they all experience some degree of bycatch (see Table S5 in Supplement 1, available at: www. int-res.com/articles/ suppl/n009p049_app.pdf). Modifications to purse seine gear and fishing practices have been successfully implemented in a US fishery in the eastern tropical Pacific Ocean where bycatch of 4 dolphin species once averaged group sizes of 400 to 500 ind. per haul and occasionally resulted in more than 1000 captured dolphins (see Hall 1998, Hall et al. 2000). On the US east coast, purse seine fisheries do not experience this same high level of marine mammal bycatch. Currently, there are no bycatch mitigation measures in place for purse seine fisheries within the study area.

\section{Dredges}

Four commercial dredge fisheries on the US east coast were included in the present review, 2 of which had documented bycatch (see Table S6 in Supplement 1, available at: www.int-res.com/articles/suppl/ n009p049_app.pdf). No marine mammal bycatch was documented in the dredge fisheries. The Gulf of Maine and Mid-Atlantic sea scallop dredge fishery was the dredge fishery with the most documented bycatch on the US east coast, including bycatch of 4 sea turtle species (Table S6). Recent bycatch measures have been put into place for this fishery to 
address sea turtles that interact with dredge gear as it passes through the water column (Table 3) (NOAA 2008d). No measures currently address interactions that occur on the sea floor where the gear operates; however, experimental gear has been tested to develop a modified dredge that will guide turtles over the top of the gear instead of under it, an occurrence which often results in injury or death (Milliken et al. 2007). Additional modifications to the experimental gear and subsequent testing are still needed before modified dredges to address seafloor interactions with turtles can be implemented in the fishery.

\section{Pound nets, stop nets, seines and weirs}

Eight commercial pound net, stop net, seine, and weir fisheries on the US east coast were analyzed (see Table S7 in Supplement 1, available at: www.intres.com/articles/suppl/n009p049_app.pdf). Six of these fisheries resulted in documented bycatch; however, the Virginia pound net fishery is the only one which has bycatch management in place (Table 3). The modifications in this fishery are designed to prevent sea turtles from becoming entangled in the pound net leaders (NOAA 2008c).

\section{CONCLUSIONS}

The present study successfully consolidated the available information on documented and potential bycatch in 49 commercial fisheries on the US east coast. The resulting tables provide a comprehensive resource for scientists, managers, and other conservation practitioners on bycatch of protected species and other species of concern in commercial fishing gear in the study area. Of the fisheries investigated, the MidAtlantic and Northeast gillnet fisheries and the Atlantic Ocean, Caribbean, and Gulf of Mexico large pelagic longline fisheries had the highest number of documented bycatch species. Twenty of the fisheries reviewed, including these 3 gillnet and pelagic longline fisheries, have either regulatory or voluntary measures in place to address bycatch, although these measures are generally implemented to address bycatch of a single species or taxonomic group (Table 3).

The results begin to highlight some of the areas where bycatch research and management is of utmost importance. It is clear that bycatch of ESA-listed species in commercial fisheries should be a priority, particularly where species are extremely endangered, global populations are low, and high bycatch exists. Bycatch reduction efforts should also focus on species with slow life histories, such as slow maturation rates, long gestation periods, and long periods of maternal care, which are exhibited by marine mammal species and other taxonomic groups. The tables help to identify where these interactions are known or are likely to occur.

However, some care should be taken when drawing conclusions and prioritizing areas of research and management based solely on these tables. For instance, 3 fisheries emerged as having the highest number of species that were documented as bycatch. While it is known that bycatch of multiple species does occur in these fisheries, it is possible that they emerged with the most documented bycatch as a result of high observer coverage. It is also possible that they are simply operating in the most highly diverse geographic areas. Fisheries with a large number of documented bycatch species are, in many cases, already the focus of existing management efforts. Fisheries with less bycatch may have resulted from less observer coverage, or they may simply experience low levels of bycatch.

The information presented in the tables does not say anything about whether bycatch interactions are sustainable, but simply whether these exist or are likely. All documented bycatch was included regardless of how often it occurred. Although some interactions are extremely rare, they are still included since they may still threaten species with small populations or low reproductive rates or in fisheries with high or increasing effort. A fishery does not have to interact with many species for bycatch to be a conservation concern, since unsustainable bycatch of a single stock or species may be occurring. Thus, these limitations must be taken into consideration when using the information presented in the tables.

Despite these limitations, this study provides a resource for scientists, managers, and other conservation practitioners to gain a better understanding of where bycatch of multi-species and multi-taxa is occurring within the study area and where management or mitigation measures either exist or are still needed. Bycatch is a problem that is not going to go away, and as populations of marine species continue to be overexploited or threatened by emerging conservation concerns, it will become even more important to reduce the incidental capture of protected and threatened marine populations.

Acknowledgements. This work was conducted for the New England Aquarium's Consortium for Wildlife Bycatch Reduction and was prepared under award NA06NMF4520120 from NOAA, US Department of Commerce. The statements, findings, conclusions, and recommendations are those of the author and do not necessarily reflect the views of the NOAA or the US Department of Commerce. T. Werner and S. Kraus at the Consortium provided project support and guidance. I 
thank J. Watson (formerly NOAA) for his valuable comments on this manuscript. Numerous NOAA employees provided information and feedback on the tables in the study, including S. Horstman, A. Johnson, D. Borggaard, K. Damon-Randall, S. Laporte, D. Hartley, M. Cavanaugh, C. Keith, M. Andersen, D. Stevenson, H. Milliken, P. Scida, E. Keane, L. Lankshear, M. Minton, J. Kenney, J. Higgins, J. Mitchell, D. Klemm, A. Ney, S. Norton, M. Warden, K. Murray, M. Asaro, S. McNulty, G. Salvador, and A. Rosner. From the University of New Hampshire, T. Ford, A. Rosenberg, R. Feeney, K. LaValley, J. Cournane, K. Alexander, B. Leavenworth, and E. Klein provided feedback early on in the study. Valuable input and information was also provided by J. Mandelman (New England Aquarium), S. Green (Maryland Sea Grant), J. Harrington (MRAG Americas), C. Watson (Fish and Wildlife Service), N. Mihnovets (State of New York), N. Young (University of St. Andrews), and 2 anonymous reviewers.

\section{LITERATURE CITED}

Acropora Biological Review Team (2005) Atlantic Acropora status review document. Report to National Marine Fisheries Service, Southeast Regional Office, St. Petersburg, FL

Alverson D, Freeberg M, Murawski S, Pope J (1996) A global assessment of fisheries bycatch and discards. United Nations FAO Tech Pap 339, FAO, Rome

Anonymous (2007) Northeast region standardized bycatch reporting methodology, an omnibus amendment to the fishery management plans of the Mid-Atlantic and New England Regional Fishery Management Councils. Prepared by the New England Fishery Management Council, Mid-Atlantic Fishery Management Council, National Marine Fisheries Service, and Northeast Regional Office

ASMFC (Atlantic States Marine Fisheries Commission) (2007) Special report to the ASMFC Atlantic Sturgeon Management Board: estimation of Atlantic sturgeon bycatch in coastal Atlantic commercial fisheries of New England and the Mid-Atlantic. Atlantic States Marine Fisheries Commission, Washington, DC

ATGTRT (Atlantic Trawl Gear Take Reduction Team) (2008) Atlantic Trawl Gear Take Reduction Strategy (ATGTRS). National Marine Fisheries Service, Atlantic Trawl Gear Take Reduction Team, Research and Education and Outreach Subgroups, NOAA, Northeast Regional Office, Gloucester, MA

Barlow J, Cameron GA (2003) Field experiments show that acoustic pingers reduce marine mammal bycatch in the California drift gill net fishery. Mar Mamm Sci 19:265-283

Borggaard D, Higgins J, Salvador G (2008) The Atlantic large whale take reduction plan, an evolving plan to reduce the risk to North Atlantic large whales (right, humpback, and fin) posed by commercial trap/pot and gillnet fishing gear in the U.S. Atlantic Ocean. NOAA, Northeast Regional Office Gloucester, MA

Brothers NP, Cooper J, Lokkeborg S (1999) The incidental catch of seabirds by longline fisheries: worldwide review and technical guidelines for mitigation. FAO Fisheries Circular No. 937, FAO, Rome

Cox TM, Read AJ, Swanner D, Urian K, Waples D (2003) Behavioral responses of bottlenose dolphins, Tursiops truncatus, to gillnets and acoustic alarms. Biol Conserv 115:203-212

Cramer J (2004) Life after catch and release. Mar Fish Rev 66:27-30

DeAlteris J (1999) Design, testing, and evaluation of an acoustic release system for offshore lobster pot buoy lines.
Final Report to the National Marine Fisheries Service. Project No. 40EANF800065

Donoghue M, Reeves RR, Stone GS (2003) Report on the workshop on interactions between cetaceans and longline fisheries. Apia, Samoa. New England Aquarium Aquatic Forum Series Report 03-1. New England Aquarium Press, Boston, MA

Fairfield-Walsh C, Garrison LP (2007) Estimated bycatch of marine mammals and turtles in the U.S. Atlantic pelagic longline fleet during 2006. NOAA Tech Memo NMFSSEFSC-560

Gibson D, Isakssen B (1998) Functionality of a full-sized marine mammal exclusion device. Sci Conserv :81, Dept of Conservation, Wellington

Gilman E, Zollett E, Beverly S, Nakano H and others (2006) Reducing sea turtle by-catch in pelagic longline gear. Fish Fish 7:2-23

Hall MA (1996) On bycatches. Rev Fish Biol Fish 6:319-352

Hall MA (1998) An ecological view of the tuna-dolphin problem: impacts and trade-offs. Rev Fish Biol Fish 8:1-34

Hall MA, Alverson DL, Metuzals KI (2000) By-catch: problems and solutions. Mar Pollut Bull 41(1-6): 204-219

Le Boeuf N (2007) Bycatch summary from seabird plans, bycatch and fisheries interaction references from key background documents. NOAA Fisheries, Office of International Affairs, Silver Spring, MD

> Mandelman JW, Cooper PW, Werner TB, Lagueux KM (2008) Shark bycatch and depredation in the U.S. Atlantic pelagic longline fishery. Rev Fish Biol Fish 18:427-442

Melvin EF, Parrish JK, Conquest LL (1999) Novel tools to reduce seabird bycatch in coastal gillnet fisheries. Conserv Biol 13:1386-1397

Milliken HO, Belskis L, DuPaul W, Gearhart J and others (2007) Evaluation of a modified scallop dredge's ability to reduce the likelihood of damage to loggerhead sea turtle carcasses. US Dept of Commerce, Northeast Fisheries Science Center Ref. Doc. 07-07

Moore JE, Wallace BP, Lewison RL, Zydelis R, Cox TM, Crowder LB (2009) A review of marine mammal, sea turtle, and sea bird bycatch in USA fisheries and the role of policy in shaping management. Mar Policy 33:435-451

NMFS (National Marine Fisheries Service) (2002) Endangered Species Act - Section 7: Consultation biological opinion. Shrimp trawling in the southeastern United States, under the sea turtle conservation regulations and as managed by the fishery management plans for shrimp in the South Atlantic and Gulf of Mexico. National Marine Fisheries Service, Southeast Region, St. Petersburg, FL

NMFS (2008) Report of the U.S. longline bycatch reduction assessment and planning workshop. NOAA Tech Memo NMFS-OPR-41, Southeast Regional Office, St. Petersburg, FL

NMFS (2009) Smalltooth sawfish recovery plan (Pristis pectinata). National Marine Fisheries Service, National Oceanic and Atmospheric Administration, Southeast Regional Office, St. Petersburg, FL

NMFS \& USFWS (2008) Recovery plan for the Northwest Atlantic population of the loggerhead sea turtle (Caretta caretta), 2nd rev. National Marine Fisheries Service, Silver Spring, MD

NOAA (1995) Stock assessment reports. NOAA National Marine Fisheries Service, Office of Protected Resources, Silver Spring, MD

NOAA (1998a) Stock assessment report. NOAA National Marine Fisheries Service, Office of Protected Resources, Silver Spring, MD

NOAA (1998b) Taking of marine mammals incidental to commercial fishing operations; harbor porpoise take reduction 
plan regulations; final rule. U.S. Dept of Commerce, 50 CFR Part 229. Fed Regist 63:66464-66490

NOAA (1999) Taking of marine mammals incidental to commercial fishing operations; Atlantic large whale take reduction plan regulations; final rule. U.S. Dept of Commerce, 50 CFR Part 229. Fed Regist 64:7529-7556

NOAA (2002a) Stock assessment report. NOAA National Marine Fisheries Service, Office of Protected Resources, Silver Spring, MD

NOAA (2002b) Sea turtle conservation; restrictions to fishing activities; final rule. US Dept of Commerce, 50 CFR Part 223. Fed Regist 67:56931-56934

NOAA (2002c) Sea turtle conservation; restrictions to fishing activities; final rule. U.S. Dep of Commerce, 50 CFR Parts 222 and 223. Fed Regist 67(232):71895-71900

NOAA (2002d) Endangered and threatened wildlife and plants; 12 -month finding for a petition to list barndoor skate (Dipturus laevis) as threatened or endangered. National Oceanic and Atmospheric Administration, National Marine Fisheries Service. Fed Regist 67:6105561061

NOAA (2004) Atlantic highly migratory species (HMS); pelagic longline fishery; final rule. US Dept of Commerce, 50 CFR Part 223 and 635. Fed Regist 69:40734-40758

NOAA (2005) Stock assessment reports. NOAA National Marine Fisheries Service, Office of Protected Resources, Silver Spring, MD

NOAA (2006) Taking of marine mammals incidental to commercial fishing operations; bottlenose dolphin take reduction plan regulations; sea turtle conservation; restrictions to fishing activities; final rule. US Dept of Commerce, 50 CFR Parts 223 and 229. Fed Regist 71:24776-24797

NOAA (2007a) Stock assessment reports. NOAA National Marine Fisheries Service, Office of Protected Resources, Silver Spring, MD

NOAA (2007b) Species of concern. NOAA National Marine Fisheries Service, Office of Protected Resources, Silver Spring, MD

NOAA (2008a) List of fisheries for 2009; final rule. US Dept of Commerce, 50 CFR Part 229. Fed Regist 73:73032-73076

NOAA (2008b) Species of concern. NOAA National Marine Fisheries Service, Office of Protected Resources, Silver Spring, MD

NOAA (2008c) Sea turtle conservation; fishing gear inspection program; final rule. US Dept of Commerce, 50 CFR Part 223. Fed Regist 73:68348-68355

NOAA (2008d) Endangered and threatened wildlife; sea turtle conservation; final rule. US Dept of Commerce, 50 CFR Part 223. Fed Regist 73:18984-19000

NOAA (2008e) Taking of marine mammals incidental to commercial fishing operations; Atlantic Pelagic Longline Take Reduction Plan; proposed rule. US Dept of Commerce, 50 CFR Part 229. Fed Regist 73:35623-35631

NOAA (2009) Proactive conservation program: species of concern. National Oceanographic and Atmospheric Administration, Office of Protected Resources, Silver Spring, MD

Noke WD, Odell DK (2002) Interactions between the Indian River Lagoon blue crab fishery and the bottlenose dolphin, Tursiops truncatus. Mar Mamm Sci 18:819-832

Northridge S (1991) An updated world review of interactions between marine mammals and fisheries. FAO Fish Tech Pap 734, Suppl 1. FAO, Rome

Northridge S (2003a) Reduction of cetacean bycatch in pelagic trawls. Final Report to the Department for Envi- ronment, Food and Rural Affairs \& JNCCs, Project MF0733. University of St. Andrews, St. Andrews

Northridge S (2003b) Further development of a dolphin exclusion device. Final Report to the Department for Environment, Food and Rural Affairs, Project MF0735. University of St. Andrews, St. Andrews

Northridge S, Sanderson D, Mackay A, Hammond P (2003) Analysis and mitigation of cetacean bycatch in UK fisheries. Final Report to the Department for Environment Food and Rural Affairs, Project MF0726. University of St. Andrews, St. Andrews

Northridge S, Mackay A, Sanderson D, Woodcock R, Kingston R (2004) A review of dolphin and porpoise bycatch issues in the southwest of England. An occasional report to the Department for Environment, Food and Rural Affairs. University of St. Andrews, St. Andrews

Read AJ (2000) Potential mitigation measures for reducing the by-catches of small cetaceans in ASCOBANS waters. Report to ASCOBANS. Available at: www.service-board. de/ascobans_neu/files/AndyReadReport.pdf

Read AJ, Rosenberg AA (convenors) (2002) Draft international strategy for reducing incidental mortality of cetaceans in fisheries. http://www.cetaceanbycatch.org/intlstrategy. cfm (accessed on March 14, 2005)

Read AJ, Drinker P, Northridge S (2006) Bycatch of marine mammals in U.S. and global fisheries. Conserv Biol 20: 163-169

SAFMC (2004) Final amendment 6 to the fishery management plan for the shrimp fishery of the South Atlantic region. South Atlantic Fishery Management Council, North Charleston, SC

SAFMC (2008) Snapper grouper amendment 15B. South Atlantic Fishery Management Council, North Charleston, $\mathrm{SC}$

Shah A, Watson J, Foster D, Epperly S (2004) Experiments in the western Atlantic northeast distant waters to evaluate sea turtle mitigation measures in the pelagic longline fishery. Summary of statistical analysis. National Marine Fisheries Service, Pascagoula, MS

Trippel EA, Holy NL, Palka DL, Shepherd TD, Melvin GD, Terhune JM (2003) Nylon barium sulphate gillnet reduces porpoise and seabird mortality. Mar Mamm Sci 19: 240-243

USFWS (2000) Stock assessment report, West Indian manatee (Trichechus manatus latirostris): Florida Stock. US Fish and Wildlife Service, Jacksonville, FL

Watson J, Foster D, Epperly S, Shah A (2003) Experiments in the western Atlantic northeast distant waters to evaluate sea turtle mitigation measures in the pelagic longline fishery. Report on experiments conducted in 2001 and 2002. National Marine Fisheries Service, Pascagoula, MS

Watson J, Foster D, Epperly S, Shah A (2004) Experiments in the western Atlantic northeast distant waters to evaluate sea turtle mitigation measures in the pelagic longline fishery. Report on experiments conducted in 2001-2003. National Marine Fisheries Service, Pascagoula, MS

Watson J, Epperly S, Foster D, Shah A (2005) Fishing methods to reduce sea turtle mortality associated with pelagic longlines. Can J Fish Aquat Sci 62:965-981

Zollett EA, Read AJ (2006) Depredation of catch by bottlenose dolphins (Tursiops truncatus) in the Florida king mackerel (Scomberomorus cavalla) troll fishery. Fish Bull (Wash DC) 104:343-349 